\title{
Grazing intensity affects forage accumulation and persistence of Marandu palisadegrass in the Brazilian savannah
}

\author{
Valéria P. B. Euclides ${ }^{1}$ (D) | Denise B. Montagner ${ }^{1}$ (D) | Manuel Cláudio M. Macedo ${ }^{1}$ \\ Alexandre R. de Araújo ${ }^{1}$ (D) | Gelson S. Difante ${ }^{2}$ (D) | Rodrigo A. Barbosa ${ }^{1}$ (D)
}

${ }^{1}$ Embrapa Beef Cattle, Campo Grande, Brazil

${ }^{2}$ Federal University of Mato Grosso do Sul,

Campo Grande, Brazil

Correspondence

Denise B. Montagner, Pasture Management, Embrapa Beef Cattle, Campo Grande, Brazil.

Email: denise.montagner@embrapa.br

Funding information

Fundação de Apoio ao Desenvolvimento do Ensino, Ciência e Tecnologia do Estado de

Mato Grosso do Sul; Conselho Nacional de

Desenvolvimento Científico e Tecnológico

\begin{abstract}
This 3-year study evaluated the effects of grazing intensity on herbage and steer responses in continuously stocked Brachiaria brizantha cv. Marandu pasture in the Brazilian savanna. Treatments consisted of three grazing intensity levels, characterized by canopy heights of 15, 30 and $45 \mathrm{~cm}$, measured twice per week. Responses variables included tiller population density (TPD), herbage accumulation rate (HAR) and body weight gain per area (WGA). A decline in TPD (1,237 vs. 767 tillers $\left./ \mathrm{m}^{2}\right)$ was observed from the first to the third grazing years, which influenced the HAR from the first to the third years (90.1 vs. $52.4 \mathrm{~kg} \mathrm{ha}^{-1}$ day $^{-1}$ ). A marked decline in body WGA ( $541 \mathrm{vs.} 276 \mathrm{~kg} \mathrm{ha}^{-1}$ year $^{-1}$ ) was observed along the three years in pastures managed at a height of $15 \mathrm{~cm}$, indicating that this is an unstable condition for Marandu palisadegrass pasture. HAR was similar for pastures managed at 30 or $45 \mathrm{~cm}$ and was relatively stable during the experimental period, averaging 91.8 and $99.1 \mathrm{~kg} \mathrm{ha}^{-1} \mathrm{day}^{-1}$ respectively. Body WGA was similar and constant throughout the experimental period for pastures managed at $30\left(596 \mathrm{~kg} \mathrm{ha}^{-1} \mathrm{year}^{-1}\right)$ and $45 \mathrm{~cm}\left(566 \mathrm{~kg} \mathrm{ha}^{-1} \mathrm{year}^{-1}\right)$. Maintaining continuously stocked Marandu palisadegrass pastures at a $15 \mathrm{~cm}$ canopy height should be avoided due to long-term decreases in plant persistence and animal body WGA, particularly when soil $P$ is below critical levels at pasture establishment and during pasture utilization.
\end{abstract}

\section{KEYWORDS}

canopy structure, grazing intensity, herbage intake, nutritive value, tiller population

\section{INTRODUCTION}

It is estimated that in Cerrado (central-west savanna) regions of Brazil, there are at least 32 million ha of degraded pastures (Andrade, Bolfe, Victoria, \& Nogueira, 2016), that is, areas characterized by a drop in regrowth vigour. These areas experience reduced carrying capacity and lower animal production, which results in great economic and environmental damage. According to the FAO (2009), approximately $20 \%$ of the world's pastures have been degraded to some extent, mainly by overgrazing. Pasture degradation is generally a consequence of a mismatch between livestock density and the capacity of the pasture to recover from grazing and trampling. Thus, knowledge of the carrying capacity of a pasture (Allen et al., 2011) enables guidelines to be drawn up that can help to avoid and even reverse pasture degradation.

The selection of a grazing intensity is more important than any other single grazing management decision because it determines the persistence of pasture and the level of production per animal and per unit land area. In this context, continuously stocked Marandu palisadegrass pastures were grazed to maintain canopy heights of 10,20 , 30 and $40 \mathrm{~cm}$, and plant and animal performance were monitored during a 1-year period (Da Silva et al., 2013). The authors concluded 
that rates of herbage accumulation were relatively stable for canopies maintained at $20-40 \mathrm{~cm}$, with little difference in nutritive value. These results were obtained in high-fertility soil and in soil fertilized with $300 \mathrm{~kg} \mathrm{~N} / \mathrm{ha}$.

However, approximately half of the beef cattle herd and planted pastures in Brazil are located in the central-west savanna, where the soil is characterized as deficient in important nutrients such as calcium, magnesium and mainly phosphorus, very oxidized, high in iron and aluminium, and prone to weathering and degradation (Chapin, Matson, \& Vitousek, 2012). Thus, our objectives were to evaluate the effect of grazing height on herbage accumulation, animal body weight gain and canopy persistence of continuously stocked Brachiaria brizantha cv. Marandu pasture in the Brazilian savanna.

\section{2 | MATERIALS AND METHODS}

\section{1 | Study site, treatments and experimental design}

The experiment was carried out at the National Beef Cattle Research Center in Campo Grande, MS, Brazil $\left(20^{\circ} 27^{\prime} \mathrm{S}, 54^{\circ} 37^{\prime} \mathrm{W}\right.$, altitude $530 \mathrm{~m}$ ), from December 2006 to December 2009. According to
Köppen's classification, the climate is a rainy tropical savanna, subtype Aw, characterized by seasonal rain distribution, with a dry winter period (May to September).

The climatic data for the experimental period (Figure 1) were collected from a weather station, approximately $2 \mathrm{~km}$ away from the experimental area. The water balance in the soil (Figure 2) was calculated using the method of Thornthwaite and Mather (1955).

The experiment was installed in a pasture area of B. brizantha cv. Marandu (Marandu palisadegrass) established in 2000 in a clayey (29\%-34\%) and dystrophic (10\%-15\%) Oxisol (Calvano et al., 2011; EMBRAPA, 2018; USDA, 2014). In May 2006 (before the start of the experiment), 2008, 2009 and 2010 (after the end of the experiment), soil samples were collected and analysed for chemical composition (Table 1). Based on these analyses and the required nutrient supply for a conservative stocking rate of Marandu palisadegrass, considered to be a cultivar requiring moderate soil fertility (EMBRAPA, 2017; Martha Junior, Vilela, \& Sousa, 2007), in October 2006, pastures were fertilized with $18 \mathrm{~kg} \mathrm{P} / \mathrm{ha}, 33 \mathrm{~kg} \mathrm{~K} / \mathrm{h}$ a and $50 \mathrm{~kg} \mathrm{~N} / \mathrm{ha}$ at the beginning of the experimental trial. $\mathrm{P}$ and $\mathrm{K}$ fertilizer were broadcasted as pasture maintenance to keep pasture persistence and animal production

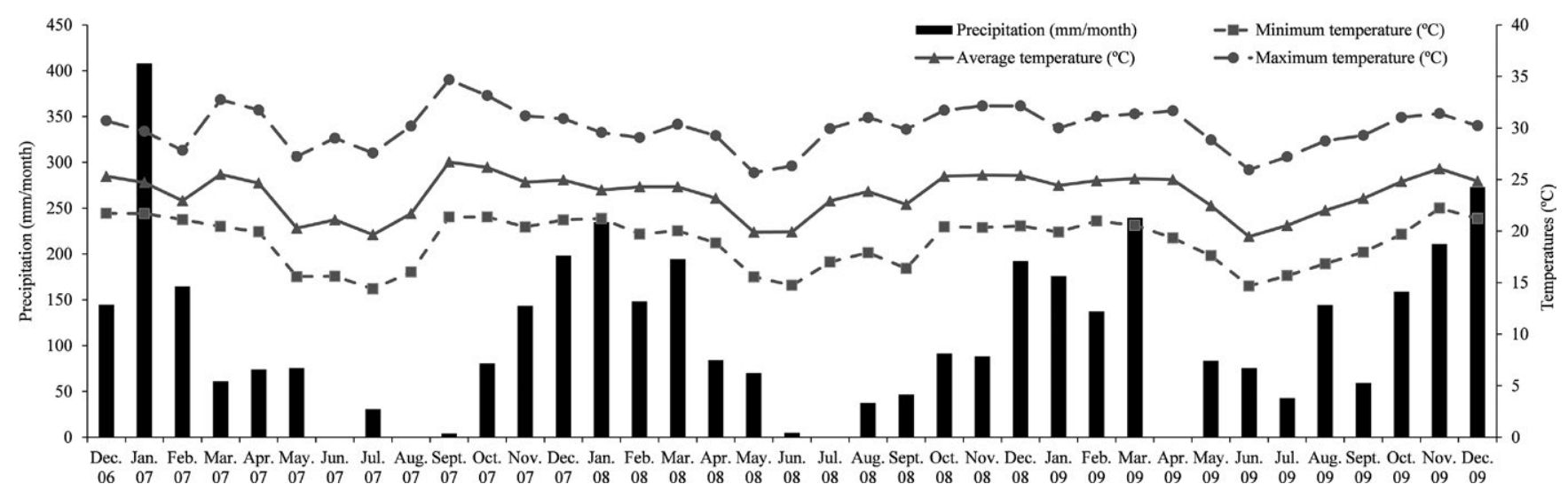

FIGURE 1 Precipitation and average, minimum and maximum temperatures during the experimental period. The historical 30-year average rainfall can be found at https://www.climatempo.com.br/climatologia/212/campogrande-ms

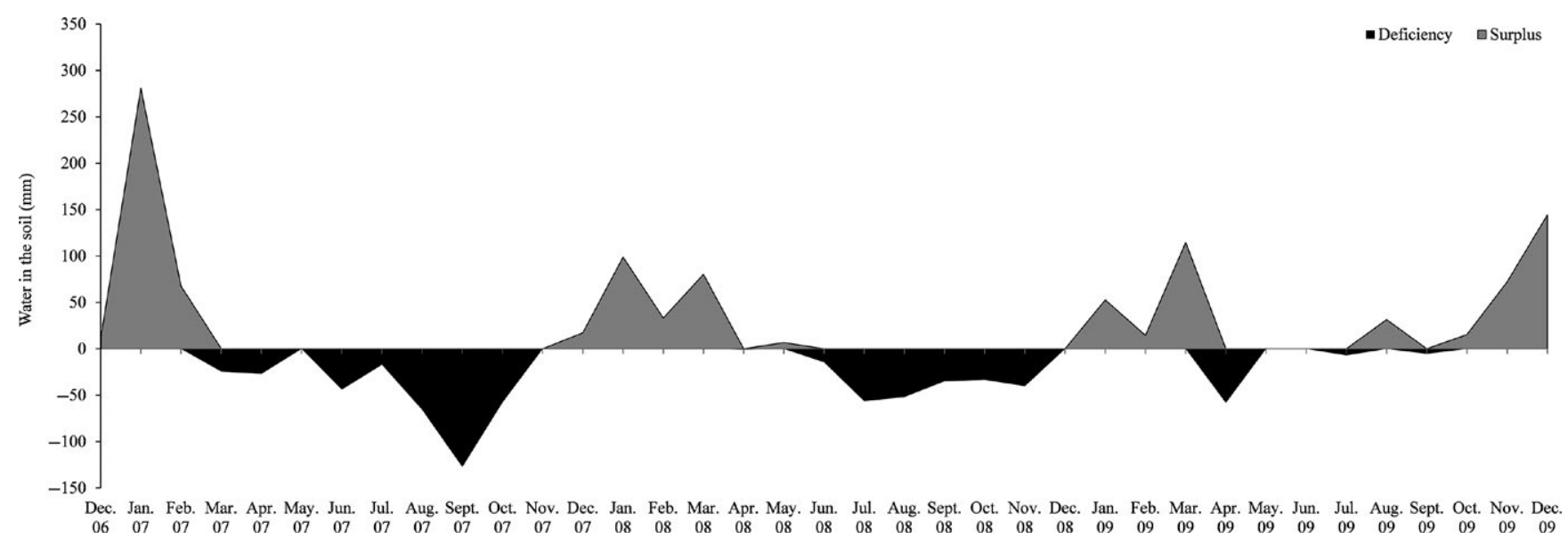

FIGURE 2 Water deficit and excess in the soil during the experimental period 
TABLE 1 Soil chemical characteristics $(0-10 \mathrm{~cm})$ throughout the experimental period

\begin{tabular}{|c|c|c|c|c|c|c|c|c|c|c|}
\hline \multirow[b]{2}{*}{ Chemical characteristics } & \multirow[b]{2}{*}{2006} & \multicolumn{3}{|l|}{2008} & \multicolumn{3}{|l|}{2009} & \multicolumn{3}{|l|}{2010} \\
\hline & & $15 \mathrm{~cm}$ & $30 \mathrm{~cm}$ & $45 \mathrm{~cm}$ & $15 \mathrm{~cm}$ & $30 \mathrm{~cm}$ & $45 \mathrm{~cm}$ & $15 \mathrm{~cm}$ & $30 \mathrm{~cm}$ & $45 \mathrm{~cm}$ \\
\hline $\mathrm{pH}-\mathrm{CaCl}_{2}$ & 5.42 & 5.49 & 5.46 & 5.44 & 5.43 & 5.31 & 5.50 & 5.52 & 5.51 & 5.45 \\
\hline $\mathrm{Ca}^{++}\left(\mathrm{cmol}_{\mathrm{c}} / \mathrm{dm}^{3}\right)$ & 2.30 & 2.97 & 2.89 & 2.82 & 2.83 & 2.44 & 2.77 & 2.99 & 2.71 & 2.87 \\
\hline $\mathrm{Mg}^{++}\left(\mathrm{cmol}_{\mathrm{c}} / \mathrm{dm}^{3}\right)$ & 1.83 & 2.10 & 2.14 & 2.08 & 1.84 & 1.54 & 1.88 & 1.94 & 1.81 & 1.90 \\
\hline $\mathrm{H}+\mathrm{Al}\left(\mathrm{cmol}_{\mathrm{c}} / \mathrm{dm}^{3}\right)$ & 3.39 & 3.12 & 3.38 & 3.47 & 3.94 & 3.59 & 3.49 & 3.94 & 3.58 & 3.51 \\
\hline $\mathrm{S}\left(\mathrm{cmol}_{\mathrm{c}} / \mathrm{dm}^{3}\right)$ & 4.36 & 5.46 & 5.37 & 5.28 & 4.85 & 4.20 & 4.90 & 5.13 & 4.84 & 5.05 \\
\hline $\mathrm{T}\left(\mathrm{cmol}_{\mathrm{c}} / \mathrm{dm}^{3}\right)$ & 7.76 & 8.58 & 8.76 & 8.75 & 8.79 & 7.80 & 8.39 & 9.08 & 8.42 & 8.56 \\
\hline $\mathrm{V}(\%)$ & 56.17 & 63.80 & 61.53 & 59.93 & 54.95 & 54.07 & 58.31 & 56.57 & 57.41 & 58.25 \\
\hline m (\%) & 0.00 & 0.32 & 0.52 & 0.91 & 0.48 & 0.82 & 0.56 & 0.07 & 0.03 & 0.04 \\
\hline $\mathrm{OM}(\%)$ & 4.81 & 4.03 & 4.25 & 4.04 & 4.47 & 4.42 & 4.73 & 5.13 & 5.28 & 5.47 \\
\hline P-Mehlich-1 (mg/dm³) & 3.64 & 1.56 & 1.88 & 2.48 & 2.65 & 2.79 & 3.38 & 2.59 & 2.48 & 3.49 \\
\hline $\mathrm{K}^{+}-$Mehlich-1 $\left(\mathrm{mg} / \mathrm{dm}^{3}\right)$ & 89.77 & 152.49 & 132.94 & 148.58 & 70.38 & 86.02 & 97.75 & 78.20 & 125.12 & 109.48 \\
\hline
\end{tabular}

Note. m: aluminium saturation; OM: organic matter; S: sum of bases; T: cation exchange capacity (pH 7); V: base saturation.

sustainable. Thus, in January 2008 and March 2009, applications of $18 \mathrm{~kg} \mathrm{P} / \mathrm{ha}$ and $33 \mathrm{~kg} \mathrm{~K} / \mathrm{ha}$ were broadcasted over pasture canopies. Nitrogen fertilizer was applied as urea in January and March of each grazing year, with each application equivalent to $45 \mathrm{~kg} \mathrm{~N} /$ ha. Dolomitic limestone was applied to the entire area from 2000 to 2003 , reaching a total of $8.5 \mathrm{t} / \mathrm{ha}$. Dolomitic limestone was first broadcasted and incorporated into the soil (3.0 t/ha) in 2000, and the remaining doses were annually broadcasted over pasture canopies. This procedure had the objective of reaching values of $45 \%-50 \%$ of soil base saturation and keeping soil $\mathrm{Ca}$ and $\mathrm{Mg}$ over 1.5 and $0.5 \mathrm{cmol}_{\mathrm{C}} / \mathrm{dm}^{3}$, respectively, in the arable layer. The targets for soil $\mathrm{P}$ and $\mathrm{K}$ (Mehlich-1) at pasture establishment (20002001) were 6-9 and 55-60 mg/dm ${ }^{3}$ respectively. During pasture utilization, the targets for soil $\mathrm{P}$ and $\mathrm{K}$ were $4-6$ and $55-60 \mathrm{mg} /$ $\mathrm{dm}^{3}$ respectively. These soil fertility requirements and procedures are explained in Martha Junior et al. (2007).

From December 2005 to September 2006, Marandu palisadegrass pastures were grazed under continuous stocking by cattle for target canopy heights of 15, 25 and $35 \mathrm{~cm}$ (Calvano et al., 2011). From then, the canopy height was monitored on a weekly basis, and the average canopy heights were 14.2, 28.5 and $41.8 \mathrm{~cm}$ (for target heights of 15, 30 and $45 \mathrm{~cm}$ ) in December 2007.

The experimental area consisted of six paddocks with an area of 0.67 ha organized in a completely randomized block design with three treatments and two replicates. Treatments corresponded to three canopy heights $(15,30$ and $45 \mathrm{~cm})$, which were generated by continuous stocking and kept on target using a variable stocking rate.

Each paddock was grazed by three Nelore steers which were approximately 14 months old and had a mean initial weight of $230 \pm 14 \mathrm{~kg}$. The groups of three steers remained in the same paddocks for one rainy season as tester animals, after which they were replaced by other animals of the same category. Twenty-two steers were kept in a reserve pasture ( 4.5 ha Marandu palisadegrass) and used as necessary to maintain canopy height targets. The stocking rate was adjusted twice a week, and the average canopy height in paddocks was allowed to vary by $10 \%$ around the target.

However, during the dry season, due to the small size of the paddocks ( $0.67 \mathrm{ha}$ ) relative to the body weight of the steers, the decision was made to reduce the number of tester steers to two per paddock. Nevertheless, there were times when those animals were removed from the experimental units and placed in the reserve pasture, and the number of days without grazing was recorded. In these cases, the animal performance was not accounted for.

\section{2 | Pasture measures}

Twice per week, the canopy surface heights were monitored using a ruler through systematic readings performed along four transect lines (15 measurement points per transect). The readings of canopy non-extended leaf height were taken from ground level to the "leaf horizon" on the top of the canopy as a reference.

Every 14 days, light interception and leaf area index were measured using canopy analyser equipment (AccuPAR Linear PAR/LAI Ceptometer, Model PAR-80; Decagon Devices) at 60 random points per paddock. At each point, one reading was performed in the soil, and one reading was performed above the canopy.

Monthly, basal, aerial and reproductive (visible flower heads) tillers were counted within eight $(1.0 \times 0.25 \mathrm{~m})$ frames randomly placed in each paddock. Measurements of tillering dynamics were made using eight $0.25 \times 0.25 \mathrm{~m}$ frames anchored in the soil by metallic staples. All tillers inside the rings were labelled with single-coloured plastic-coated wires at first tagging. Every 28 days, a new colour was used to identify the new generation of tillers that appeared, and surviving ones were counted throughout the experimental period. Thus, tillers from all generations were counted every 4 weeks. The stability index corresponded to the ratio between the tiller population in month 1 and month 0 and was calculated according to Bahmani, Thom, Matthew, Hopper, and Lemaire (2003). 


\subsection{Herbage mass, morphological composition and herbage accumulation rate}

Every 28 days, fifteen random samples $(1 \times 1 \mathrm{~m})$ per experimental unit were harvested at ground level. The cut was performed using a manual mower. The samples were divided into two subsamples: one was used for estimating forage mass, and the other was separated into leaf (leaf blade), stem (sheath and stem) and dead material. Details of sample processing were described by Euclides, Montagner, Barbosa, Valle, and Nantes (2016). At the same time, the herbage accumulation rate (HAR) was estimated using three exclusion cages $\left(1 \mathrm{~m}^{2}\right)$ for each paddock; details of sampling and calculations have been given by Euclides et al. (2016).

Monthly, two hand-plucked samples (Sollenberger \& Cherney, 1995) were taken per paddock. They were dried, ground and analysed for crude protein, neutral detergent fibre and acid detergent lignin concentrations, as well as in vitro organic matter digestibility, using near-infrared spectroscopy (NIRS).

\subsection{Animal measures}

The herbage dry-matter intake was estimated in February, April and December 2007 and in February and April 2008. The marker supply, the adaptation period, the faeces collection and the calculations followed the methodology described by Valadares Filho, Paulino, and Sainz (2005). The faecal concentration of chromium was analysed as described in Williams, David, and Ilsmaa (1962).

Monthly, all steers were weighed following overnight feed and water fasting (16 hr). The body weight gain of the tester steer was used to calculate the average daily gain. The stocking rate was calculated using both tester and regulator steers and expressed in animal units (450 kg body weight) per hectare. Steer days per hectare was determined by multiplying the stocking rate by the number of days of grazing and dividing that product by the mean weight of the testers on that pasture. Gain per hectare was calculated as the product of the average daily gain and steer days per hectare.

\section{5 | Statistical analysis}

The data were analysed by season (rainy=October to April; dry = May to September) using a mixed procedure in SAS (Statistical Analysis System, version 9.4). The applied model included the random effect of the block and fixed effects of the grazing intensity, experimental year and their interactions. All data reported are least squares means, and, when appropriate, averages were compared using the Tukey test at $p<0.05$.

\section{3 | RESULTS}

The canopy heights of B. brizantha cv. Marandu (Marandu palisadegrass) pastures remained within the target range throughout the experiment (Table 2). To maintain the target heights, the pastures required some time without grazing during the dry period.

The total rainfall recorded in $2007(1,240 \mathrm{~mm})$ and 2008 $(1,190 \mathrm{~mm})$ was below the 30 -year average $(1,450 \mathrm{~mm})$ but close to the average in 2009 (1,600 mm). The overall rainfall distribution was most uniform in 2009 (Figure 1), and the dry season (405 mm) was wetter than the historical 30-year dry season (295 mm); additionally, a soil water deficit was only registered during April (Figure 2). Conversely, 2007 (110 mm) and 2008 (160 mm) showed drier weather from May to September (Figures 1 and 2). In addition, the average daily temperatures during autumn $\left(30.6^{\circ} \mathrm{C}\right)$ and spring $\left(33.1^{\circ} \mathrm{C}\right)$ of 2007 were warmer than the normal daily temperatures in autumn $\left(29.5^{\circ} \mathrm{C}\right)$ and spring $\left(31.2^{\circ} \mathrm{C}\right)$, and autumn and spring of 2007 also had the lowest rainfall distribution (Figure 1). These conditions

TAB LE 2 Actual average and standard deviation for canopy heights in Brachiaria brizantha cv. Marandu pastures subjected to continuous stocking, targeting either at 15, 30 or $45 \mathrm{~cm}$ canopy height, throughout the experimental period

\begin{tabular}{|c|c|c|c|c|c|c|c|c|c|}
\hline & \multicolumn{9}{|c|}{ Canopy height $(\mathrm{cm})$} \\
\hline January & $15.1 \pm 0.9$ & $29.2 \pm 0.2$ & $44.9 \pm 0.2$ & $15.1 \pm 0.5$ & $30.5 \pm 0.7$ & $46.6 \pm 1.2$ & $15.0 \pm 0.3$ & $31.2 \pm 0.5$ & $45.5 \pm 0.3$ \\
\hline February & $14.5 \pm 0.7$ & $30.8 \pm 07$ & $45.5 \pm 0.4$ & $15.1 \pm 0.2$ & $30.2 \pm 0.5$ & $45.2 \pm 0.8$ & $15.3 \pm 0.8$ & $30.1 \pm 1.1$ & $44.9 \pm 0.6$ \\
\hline May & $15.2 \pm 0.8$ & $28.7 \pm 0.9$ & $44.2 \pm 0.7$ & $15.2 \pm 0.2$ & $31.0 \pm 0.3$ & $45.3 \pm 0.6$ & $14.5 \pm 0.3$ & $29.6 \pm 0.6$ & $45.3 \pm 0.4$ \\
\hline June & $15.3 \pm 0.4$ & $30.0 \pm 0.3$ & $45.1 \pm 0.8$ & $15.1 \pm 0.4$ & $31.1 \pm 0.5$ & $45.0 \pm 0.6$ & $14.7 \pm 0.2$ & $29.2 \pm 0.1$ & $44.8 \pm 0.4$ \\
\hline July & $14.9 \pm 0.5$ & $30.2 \pm 0.2$ & $44.8 \pm 0.1$ & $14.6 \pm 0.8$ & $29.3 \pm 0.6$ & $43.9 \pm 0.3$ & $14.2 \pm 0.6$ & $28.9 \pm 1.1$ & $47.1 \pm 1.6$ \\
\hline August & $13.8 \pm 0.4$ & $27.2 \pm 1.1$ & $41.8 \pm 1.4$ & $14.1 \pm 0.6$ & $28.7 \pm 0.2$ & $43.7 \pm 0.4$ & $13.6 \pm 0.7$ & $28.5 \pm 1.1$ & $44.2 \pm 0.7$ \\
\hline December & $15.5 \pm 0.3$ & $31.6 \pm 0.9$ & $45.1 \pm 0.3$ & $15.6 \pm 0.1$ & $30.3 \pm 0.5$ & $45.0 \pm 0.4$ & $15.6 \pm 0.8$ & $30.2 \pm 0.3$ & $44.9 \pm 0.4$ \\
\hline
\end{tabular}


resulted in a soil water deficit in March that lasted until the beginning of November (Figure 2). In the following year, however, despite rainfall that was poorly distributed and below the 20-year average, the autumn was milder $\left(28.4^{\circ} \mathrm{C}\right)$; thus, a soil water deficit was registered from July to November (Figure 2).

\subsection{Rainy season}

An interaction between the effects of canopy height and experimental year was observed for tiller population density (TPD; $p=0.0001$ ), $\operatorname{HAR}(p=0.0001)$, stocking rate $(p=0.0001)$ and body weight gain per area (WGA; $p=0.0221$ ). During the first 2 years, the TPD decreased as canopy height increased; however, in the third year, the TPD was similar for all pastures managed at different grazing intensities. The number of tillers in pastures managed at $15 \mathrm{~cm}$ decreased from the first to the third years. In contrast, in pastures managed at 30 or $45 \mathrm{~cm}$, the TPDs were similar throughout the experimental period (Table 3).

TAB LE 3 Averages and standard errors of the mean (SEM) for tiller population density, herbage accumulation rate, stocking rate, body weight gain per area and grazing period in Brachiaria brizantha cv. Marandu pastures subjected to continuous stocking, targeting either at 15, 30 or $45 \mathrm{~cm}$ canopy height, during the wet periods of different experimental years

\begin{tabular}{|c|c|c|c|c|}
\hline \multirow[b]{2}{*}{ Years } & \multicolumn{3}{|c|}{ Canopy height $(\mathrm{cm})$} & \multirow[b]{2}{*}{ SEM } \\
\hline & 15 & 30 & 45 & \\
\hline \multicolumn{5}{|c|}{ Tiller population density (tillers $/ \mathrm{m}^{2}$ ) } \\
\hline 2007 & $1,237 \mathrm{Aa}$ & $965 A b$ & 783AC & 23 \\
\hline 2008 & $1,045 \mathrm{Ba}$ & $896 \mathrm{Ab}$ & $740 A c$ & 24 \\
\hline 2009 & $767 \mathrm{Ca}$ & 905Aa & $791 \mathrm{Aa}$ & 43 \\
\hline \multicolumn{5}{|c|}{ Herbage accumulation rate $\left(\mathrm{kg} \mathrm{ha}^{-1} \mathrm{day}^{-1}\right)$} \\
\hline 2007 & 90.1Aa & 99.2Aa & 107.6Aa & 3.9 \\
\hline 2008 & 83.1Aa & $90.6 \mathrm{Aa}$ & 96.8Aa & 3.5 \\
\hline 2009 & $52.4 \mathrm{Bb}$ & $85.6 \mathrm{Aa}$ & 92.8Aa & 4.1 \\
\hline \multicolumn{5}{|c|}{ Stocking rate (AU/ha) } \\
\hline 2007 & 3.96Aa & 3.32Ab & 2.68Ac & 0.10 \\
\hline 2008 & 3.05Ba & $2.91 \mathrm{ABa}$ & 2.43Ab & 0.11 \\
\hline 2009 & 2.72Ba & $2.85 \mathrm{Ba}$ & 2.59Aa & 0.16 \\
\hline \multicolumn{5}{|c|}{ Body weight gain per area (kg/ha) } \\
\hline 2007 & $516 \mathrm{Aa}$ & $560 A a$ & $521 \mathrm{Aa}$ & 29 \\
\hline 2008 & $399 \mathrm{ABb}$ & $586 \mathrm{Aa}$ & $552 \mathrm{Aa}$ & 28 \\
\hline 2009 & $265 \mathrm{Bb}$ & 498Aa & $464 \mathrm{Aa}$ & 30 \\
\hline \multicolumn{5}{|c|}{ Grazing period (days) } \\
\hline 2007 & 218 & 218 & 218 & - \\
\hline 2008 & 195 & 223 & 223 & - \\
\hline 2009 & 221 & 221 & 221 & - \\
\hline
\end{tabular}

Note. AU, animal units, with $1 \mathrm{AU}=450 \mathrm{~kg} \mathrm{BW}$.

Values followed by the same upper-case letter within the same column and the same lower-case letter within the same row were not significantly different according to the Tukey test at $p<0.05$.
The HAR was similar for pastures managed at different grazing intensities in 2007 and 2008. However, in 2009, the HAR was lower for pastures managed at $15 \mathrm{~cm}$ compared to those managed at 30 or $45 \mathrm{~cm}$. While no difference in HAR was observed throughout the experimental period for pastures managed at 30 or $45 \mathrm{~cm}$, pastures managed at $15 \mathrm{~cm}$ showed a lower HAR in the third year than in the first and second years (Table 3).

During the first year, the stocking rate (SR) decreased as canopy height increased; however, in 2008, the SR was similar for pastures managed at 15 or $30 \mathrm{~cm}$, and the SR for pastures managed at 15 or $30 \mathrm{~cm}$ was greater than the SR for pastures managed at $45 \mathrm{~cm}$. In 2009, SR was similar among grazing intensity treatments. Pastures managed at $15 \mathrm{~cm}$ showed greater SR during the first year compared to the SR at other pasture canopy heights. For pastures managed at $30 \mathrm{~cm}$, the SR was greater in the first year than in the third year; however, the value observed in the second year was similar to the value observed in the other years. Conversely, the SR for pastures managed at $45 \mathrm{~cm}$ remained constant throughout the experimental period (Table 3).

The body WGA was not influenced by canopy height treatments in 2007. However, in 2008 and 2009, pastures managed at 30 or $45 \mathrm{~cm}$ presented greater WGA than those managed at $15 \mathrm{~cm}$. Throughout the experimental period, pastures managed at 30 and $45 \mathrm{~cm}$ showed similar WGA. Conversely, those managed at $15 \mathrm{~cm}$ presented greater WGA in 2007 than in 2009, while the value observed in 2008 was similar to the value observed in the other years (Table 3).

The grazing period was similar for pastures managed at different grazing intensities, except in the second year when pastures managed at $15 \mathrm{~cm}$ presented a shorter grazing period than pastures managed at 30 and $45 \mathrm{~cm}$ (Table 3).

No interaction $(p>0.05)$ was observed between the effects of canopy height and experimental year for the remaining variables quantified. Additionally, the canopy height had no effect ( $p=0.1615$ ) on reproductive (TPD; $18.9 \pm 5.3$ tillers $/ \mathrm{m}^{2}$ ). However, pastures managed at $15 \mathrm{~cm}$ showed a lower leaf area index and light interception than those of the pastures managed at 30 or $45 \mathrm{~cm}$. The leaf percentage and leaf:stem ratio were greater for pastures managed at $15 \mathrm{~cm}$ than those for pastures managed at $30 \mathrm{~cm}$, which in turn were greater than for pastures managed at $45 \mathrm{~cm}$. The inverse was observed for herbage mass, stem and dead material percentages (Table 4).

Pastures managed at $45 \mathrm{~cm}$ presented lower percentages of crude protein and in vitro organic matter digestibility than those for pastures managed at 15 and $30 \mathrm{~cm}$. The neutral detergent fibre concentration was lower for the $15 \mathrm{~cm}$ treatment than for the other treatments. The acid detergent lignin concentration was lower for pastures managed at $15 \mathrm{~cm}$ than those managed at $30 \mathrm{~cm}$, and that concentration, in turn, was lower than that for pastures managed at $45 \mathrm{~cm}$ (Table 4).

Herbage intake was greater for pastures managed at $30 \mathrm{~cm}$ than for pastures managed at $15 \mathrm{~cm}$, while pastures managed at $45 \mathrm{~cm}$ showed a similar value for herbage intake as the other treatments 
TABLE 4 Averages, standard errors of the mean (SEM) and probability levels $(p)$ for leaf area index, light interception, herbage mass, percentages of leaf, stem and dead material, leaf:stem ratio, crude protein, neutral detergent fibre, acid detergent lignin concentrations, in vitro organic matter digestibility (IVOMD), herbage intake and average daily gain in Brachiaria brizantha cv. Marandu pastures subjected to continuous stocking, targeting either at 15, 30 or $45 \mathrm{~cm}$ canopy height, during the wet period

\begin{tabular}{|c|c|c|c|c|c|}
\hline & \multicolumn{3}{|c|}{ Canopy height $(\mathrm{cm})$} & \multirow[b]{2}{*}{ SEM } & \multirow[b]{2}{*}{$p$} \\
\hline & 15 & 30 & 45 & & \\
\hline $\begin{array}{l}\text { Leaf area } \\
\text { index }\end{array}$ & $2.72 b$ & $3.90 a$ & $3.96 a$ & 0.33 & 0.0341 \\
\hline $\begin{array}{l}\text { Light } \\
\text { interception } \\
(\%)\end{array}$ & $72.6 b$ & $89.3 a$ & $93.6 a$ & 2.5 & 0.0019 \\
\hline $\begin{array}{l}\text { Herbage } \\
\text { mass (kg/ } \\
\text { ha) }\end{array}$ & $2,484 c$ & $4,861 b$ & $5,827 a$ & 88 & 0.0001 \\
\hline Leaf (\%) & $51.3 a$ & $43.5 b$ & $30.8 c$ & 0.9 & 0.0001 \\
\hline Stem (\%) & $16.1 \mathrm{c}$ & $20.4 b$ & $26.2 a$ & 0.8 & 0.0001 \\
\hline $\begin{array}{l}\text { Dead } \\
\text { material (\%) }\end{array}$ & $32.6 \mathrm{c}$ & $36.1 b$ & $43.0 a$ & 1.1 & 0.0001 \\
\hline $\begin{array}{l}\text { Leaf:stem } \\
\text { ratio }\end{array}$ & $3.7 a$ & $2.2 \mathrm{~b}$ & $1.3 c$ & 0.2 & 0.0001 \\
\hline $\begin{array}{l}\text { Crude } \\
\text { protein (\%) }\end{array}$ & $13.6 a$ & $12.8 a$ & $11.0 \mathrm{~b}$ & 0.2 & 0.0001 \\
\hline $\begin{array}{l}\text { Neutral } \\
\text { detergent } \\
\text { fibre (\%) }\end{array}$ & $71.5 b$ & $73.1 \mathrm{a}$ & $74.0 a$ & 0.4 & 0.0022 \\
\hline $\begin{array}{l}\text { Acid } \\
\text { detergent } \\
\text { lignin (\%) }\end{array}$ & $2.5 c$ & $2.7 b$ & $3.0 a$ & 0.05 & 0.0001 \\
\hline IVOMD (\%) & $63.2 \mathrm{a}$ & $61.7 a$ & $59.3 b$ & 0.6 & 0.0001 \\
\hline $\begin{array}{l}\text { Herbage } \\
\text { intake } \\
\text { (kg } 100 \mathrm{~kg} / \\
\text { day) }\end{array}$ & $1.99 \mathrm{~b}$ & $2.60 a$ & $2.31 \mathrm{ab}$ & 0.1 & 0.0009 \\
\hline $\begin{array}{l}\text { Average } \\
\text { daily gain } \\
\text { (kg/steer) }\end{array}$ & $0.625 b$ & $0.755 a$ & $0.770 a$ & 0.027 & 0.0237 \\
\hline
\end{tabular}

Note. Values followed by the same letter within the same row were not significantly different according to the Tukey test at $p<0.05$.

(Table 4). The body weight gain of the steers grazing pastures managed at 30 and $45 \mathrm{~cm}$ was similar to but greater than the body weight gain of those grazing pastures managed at $15 \mathrm{~cm}$ (Table 4).

No significant differences in leaf area index $(p=0.1630)$, light interception ( $p=0.5246)$, leaf:stem ratio $(p=0.1081)$, in vitro organic matter digestibility $(p=0.1253)$ and acid detergent lignin $(p=0.0754$ ) were observed among experimental years. However, the reproductive tiller population was similar in 2008 and 2009 and greater than in 2007. Herbage mass was greater in 2008 than in the other years. The leaf percentage was greater in 2007 than in 2009, while in 2008, it was similar to the leaf percentage in other years. The stem percentage was similar for the second and third years and was greatest in the first year. The dead material percentage was lower in 2007 than in 2008 and lower in 2008 than in 2009 (Table 5).

The crude protein concentration was not significantly different between the two first years, but the crude protein concentration observed for the first 2 years was greater than that observed for the third year. The neutral detergent fibre concentration was greater in 2007 than in 2008 and 2009. The herbage intake was lower in the first year than in the second year. The average daily gain was lower in 2009 than in 2007 and 2008 (Table 5).

\section{2 | Dry season}

Except for TPD ( $p=0.0086)$ and body WGA ( $p=0.0005)$, no interaction $(p>0.05)$ was observed between the effects of canopy height and experimental year for the other variables evaluated during the dry period.

In the first 2 years, the number of tillers was equal for pastures managed at 15 and $30 \mathrm{~cm}$, which was greater than the number of tillers for pastures maintained at $45 \mathrm{~cm}$. The inverse was observed during the third year: tiller number was similar for pastures managed at 30 or $45 \mathrm{~cm}$, and that number was greater than the tiller number for pastures managed at $15 \mathrm{~cm}$. The TPD for pastures managed at 30 or $45 \mathrm{~cm}$ remained constant over the experimental period; however, for the $15 \mathrm{~cm}$ treatment, the number of tillers was lower in the third year than in the previous years (Table 6).

During the first year, pastures managed at $15 \mathrm{~cm}$ presented lower body WGA than those maintained at $30 \mathrm{~cm}$, and pastures managed at $45 \mathrm{~cm}$ presented the highest WGA. However, in 2008 and 2009, WGA was similar for pastures managed at 30 or $45 \mathrm{~cm}$, and that WGA was greater than the WGA of pastures managed at $15 \mathrm{~cm}$. Pastures managed at $15 \mathrm{~cm}$ showed similar WGA during the first 2 years, and those WGA levels were greater than the WGA for 2009. However, for the $30 \mathrm{~cm}$ treatment, WGA was lower in the first year than in the other years. In contrast, the WGA for pastures managed at $45 \mathrm{~cm}$ remained constant throughout the experimental period (Table 6).

The leaf area index, light interception and HAR were lower for pastures managed at $15 \mathrm{~cm}$ than for those managed at 30 or $45 \mathrm{~cm}$ (Table 7). The herbage mass was lower for pastures managed at 15 than for those managed at $30 \mathrm{~cm}$, which in turn was lower than for pastures maintained at $45 \mathrm{~cm}$. Pastures managed at $15 \mathrm{~cm}$ showed greater leaf percentage and leaf:stem ratio than those managed at $30 \mathrm{~cm}$, which were greater than those of pastures maintained at $45 \mathrm{~cm}$ (Table 7). The dead material percentage was greater for pastures at $45 \mathrm{~cm}$ than for those maintained at $15 \mathrm{~cm}$, and the dead material percentage for pastures at $30 \mathrm{~cm}$ was similar to those observed at other heights (Table 7). On the other hand, stem percentage $(p=0.2578)$ and reproductive tiller population $(p=0.2350)$ were not different among pastures managed at different canopy heights. The average values and standard errors were $14.7 \pm 1.2 \%$ and $30.9 \pm 6.3$ tillers $/ \mathrm{m}^{2}$ respectively.

The crude protein concentration was similar for pastures managed at 15 or $30 \mathrm{~cm}$, and that value was greater than the value for 
TABLE 5 Averages, standard errors of the mean (SEM) and probability levels ( $p$ ) for reproductive tiller population, herbage mass, percentages of leaf, stem and dead material, crude protein, neutral detergent fibre, acid detergent lignin concentrations and herbage intake in Brachiaria brizantha cv. Marandu pastures subjected to continuous stocking, targeting either at 15,30 or $45 \mathrm{~cm}$ canopy height, during the wet periods of different experimental years

\begin{tabular}{|c|c|c|c|c|}
\hline & \multicolumn{3}{|c|}{ Experimental year } & \multirow[b]{2}{*}{$p$} \\
\hline & 2007 & 2008 & 2009 & \\
\hline $\begin{array}{l}\text { Reproductive tillers (tillers/ } \\
\mathrm{m}^{2} \text { ) }\end{array}$ & $8.0 b(3.9)$ & $25.6 a(4.2)$ & $23.2 \mathrm{a}(4.3)$ & 0.0080 \\
\hline Herbage mass (kg /ha) & 4217b (111) & 4795a (111) & $4160 b(111)$ & 0.0001 \\
\hline Leaf (\%) & 43.3a (0.9) & $42.4 \mathrm{ab}(0.9)$ & $39.6 b(0.9)$ & 0.0183 \\
\hline Stem (\%) & $25.3 a(0.8)$ & $19.5 b(0.8)$ & $17.9 \mathrm{~b}(0.8)$ & 0.0001 \\
\hline Dead material (\%) & $31.3 c(1.2)$ & $38.1 \mathrm{~b}(1.2)$ & $42.5 a(1.2)$ & 0.0001 \\
\hline Crude protein (\%) & $12.9 a(0.2)$ & $13.0 \mathrm{a}(0.2)$ & $11.5 b(0.2)$ & 0.0001 \\
\hline Neutral detergent fibre (\%) & 74.0a (0.4) & $72.4 b(0.4)$ & $72.1 b(0.4)$ & 0.0097 \\
\hline $\begin{array}{l}\text { Herbage intake (kg } 100 \text { kg/ } \\
\text { day) }\end{array}$ & $2.1(0.07)$ & $2.4(0.09)$ & - & 0.0389 \\
\hline Average daily gain (kg/steer) & $0.745 a(0.02)$ & $0.775 a(0.03)$ & $0.630 \mathrm{~b}(0.03)$ & 0.0339 \\
\hline
\end{tabular}

Note. Values in parentheses are standard errors of the mean (SEM).

Values followed by the same letter within the same row were not significantly different according to the Tukey test at $p<0.05$. pastures managed at $45 \mathrm{~cm}$. Pastures managed at $15 \mathrm{~cm}$ presented a neutral detergent fibre concentration lower than the concentration of those maintained at $45 \mathrm{~cm}$, and the value observed for pastures managed at $30 \mathrm{~cm}$ was similar to the value for the other heights. The acid detergent lignin concentration was similar for pastures managed at 30 or $45 \mathrm{~cm}$, and that concentration value was greater than the value for pastures managed at $15 \mathrm{~cm}$. Pastures managed at $15 \mathrm{~cm}$ presented a greater in vitro organic matter digestibility percentage than the percentage for those managed at $30 \mathrm{~cm}$, which in turn was greater than the percentage for pastures maintained at $45 \mathrm{~cm}$ (Table 7).

The number of grazing days declined with decreasing canopy height. The stocking rate and average daily gain were not significantly different between pastures managed at 30 and $45 \mathrm{~cm}$ but were lower for the pastures managed at $15 \mathrm{~cm}$ (Table 7).

No significant differences in leaf area index $(p=0.0982)$, light interception $(p=0.0556)$, reproductive tiller population $(p=0.2350)$, stem percentage $(p=0.2636)$, leaf:stem ratio $(p=0.0665)$, neutral detergent fibre concentration $(p=0.8266)$, acid detergent lignin percentage $(p=0.1149)$ and stocking rate ( $p=0.1197$ ) were observed among experimental years. However, the year effect was observed for the remaining variables quantified (Table 8). The HAR, herbage mass and leaf percentage were greater in 2009 than in the other years. However, the dead material percentage was lower in 2009 than that observed in 2007 and 2008.

The percentages of crude protein and in vitro organic matter digestibility were greater in 2007 than in 2008, and the values observed in 2009 were similar to the values observed in other years. The number of grazing days during the dry season was greater in 2009 than in the two previous years, and the number of grazing days in 2007 and 2008 was similar to each other. The average daily gain was similar in 2007 and 2009, and those average daily gain were greater than the average daily gain in 2008 (Table 8).
TAB LE 6 Averages and standard errors of the mean (SEM) for tiller population density, body weight gain per area and grazing period in Brachiaria brizantha cv. Marandu pastures subjected to continuous stocking, targeting either at 15, 30 or $45 \mathrm{~cm}$ canopy height, during the dry period of different experimental years

\begin{tabular}{|c|c|c|c|c|}
\hline \multirow[b]{2}{*}{ Years } & \multicolumn{3}{|c|}{ Canopy height $(\mathrm{cm})$} & \multirow[b]{2}{*}{ SEM } \\
\hline & 15 & 30 & 45 & \\
\hline \multicolumn{5}{|c|}{ Tiller population density (tillers $/ \mathrm{m}^{2}$ ) } \\
\hline 2007 & 778Aa & 721Aa & $609 \mathrm{Ab}$ & 18 \\
\hline 2008 & 690Aa & 739Aa & $634 \mathrm{Ab}$ & 28 \\
\hline 2009 & $476 \mathrm{Bb}$ & $700 A a$ & 661Aa & 34 \\
\hline \multicolumn{5}{|c|}{ Body weight gain per area (kg/ha) } \\
\hline 2007 & $25 \mathrm{Ac}$ & $41 \mathrm{Bb}$ & $52 \mathrm{Aa}$ & 1.8 \\
\hline 2008 & $27 A b$ & $51 \mathrm{Aa}$ & $50 A a$ & 1.9 \\
\hline 2009 & $11 \mathrm{Bb}$ & $53 \mathrm{Aa}$ & 60Aa & 2.1 \\
\hline \multicolumn{5}{|c|}{ Grazing period (days) } \\
\hline 2007 & 63 & 87 & 108 & - \\
\hline 2008 & 56 & 94 & 105 & - \\
\hline 2009 & 65 & 123 & 144 & - \\
\hline
\end{tabular}

Note. Values followed by the same upper-case letter within the same column and the same lower-case letter within the same row were not significantly different according to the Tukey test at $p<0.05$.

\section{4 | DISCUSSION}

\section{1 | Rainy season}

Short-length grazing periods in 2007 and 2008 (Table 8) were primarily related to drier-than-normal weather which extended the dry season until November (Figures 1 and 2). An interaction between timing and grazing intensity occurred because of a $38 \%$ decrease in tiller number between the first and third years of grazing for 
TABLE 7 Averages, standard errors of the mean (SEM) and probability levels $(p)$ for leaf area index, light interception, herbage accumulation rate (HAR), herbage mass, percentages of leaf and dead material stem, leaf:stem ratio, crude protein, neutral detergent fibre and acid detergent lignin concentrations, in vitro organic matter digestibility (IVOMD), number of grazing days, stocking rate and average daily gain in Brachiaria brizantha cv. Marandu pastures subjected to continuous stocking, targeting either at 15, 30 or $45 \mathrm{~cm}$ canopy height, during the dry period

\begin{tabular}{|c|c|c|c|c|c|}
\hline & \multicolumn{3}{|c|}{ Canopy height $(\mathrm{cm})$} & \multirow[b]{2}{*}{ EPM } & \multirow[b]{2}{*}{$p$} \\
\hline & 15 & 30 & 45 & & \\
\hline $\begin{array}{l}\text { Leaf area } \\
\text { index }\end{array}$ & $2.09 \mathrm{~b}$ & $2.78 a$ & $3.11 a$ & 0.16 & 0.0010 \\
\hline $\begin{array}{l}\text { Light } \\
\text { interception } \\
\text { (\%) }\end{array}$ & $60.8 b$ & $76.7 a$ & $81.4 a$ & 3.1 & 0.0001 \\
\hline $\begin{array}{l}\operatorname{HAR}\left(\mathrm{kg} \mathrm{ha}^{-1}\right. \\
\left.\mathrm{day}^{-1}\right)\end{array}$ & $13.2 b$ & $27.1 a$ & $30.6 a$ & 2.4 & 0.0001 \\
\hline $\begin{array}{l}\text { Herbage } \\
\text { mass (kg/ } \\
\text { ha) }\end{array}$ & $2,606 c$ & $4,687 b$ & $5,503 a$ & 105 & 0.0001 \\
\hline Leaf (\%) & $24.9 a$ & $18.8 \mathrm{~b}$ & $12.2 \mathrm{c}$ & 1.1 & 0.0001 \\
\hline $\begin{array}{l}\text { Dead } \\
\text { material (\%) }\end{array}$ & $61.8 \mathrm{~b}$ & $66.4 a b$ & $72.0 a$ & 1.9 & 0.0018 \\
\hline $\begin{array}{l}\text { Leaf:stem } \\
\text { ratio }\end{array}$ & $2.0 \mathrm{a}$ & $1.4 \mathrm{~b}$ & $0.8 c$ & 0.1 & 0.0001 \\
\hline $\begin{array}{l}\text { Crude } \\
\text { protein (\%) }\end{array}$ & $9.2 \mathrm{a}$ & $8.8 a$ & $7.7 b$ & 0.3 & 0.0035 \\
\hline $\begin{array}{l}\text { Neutral } \\
\text { detergent } \\
\text { fibre (\%) }\end{array}$ & $72.3 b$ & $73.4 a b$ & $74.9 a$ & 0.6 & 0.0050 \\
\hline $\begin{array}{l}\text { Acid } \\
\text { detergent } \\
\text { lignin (\%) }\end{array}$ & $2.6 \mathrm{~b}$ & $2.8 a$ & $2.9 a$ & 0.06 & 0.0007 \\
\hline IVOMD (\%) & $57.6 a$ & $55.2 b$ & $53.2 \mathrm{c}$ & 0.6 & 0.0001 \\
\hline $\begin{array}{l}\text { Number of } \\
\text { grazing days }\end{array}$ & $59 c$ & $91 b$ & $112 \mathrm{a}$ & 3.3 & 0.0001 \\
\hline $\begin{array}{l}\text { Stocking rate } \\
\text { (AU/ha) }\end{array}$ & $0.52 b$ & $0.94 a$ & $1.13 a$ & 0.11 & 0.0012 \\
\hline $\begin{array}{l}\text { Average daily } \\
\text { gain (g/ } \\
\text { steer) }\end{array}$ & $270 b$ & $380 a$ & $365 a$ & 30 & 0.0155 \\
\hline
\end{tabular}

Note. Values followed by the same upper-case letter within the same column and the same lower-case letter within the same row were not significantly different according to the Tukey test at $p<0.05$.

pastures managed at $15 \mathrm{~cm}$. In contrast, the TPD for pastures managed at 30 or $45 \mathrm{~cm}$ was relatively constant throughout the experimental period (Table 3). This resulted in decreases of $42 \%$ in the HAR from the first to the third years for pasture that was heavily grazed; consequently, the stocking rate and body weight per area declined (Table 3). On the other hand, pastures managed leniently were capable of maintaining the HAR and, consequently, the body weight per area during the experimental period.
In the first 2 years, the values for TPD (Table 3 ) were in line with the general pattern of low tiller populations with tall canopies and high tiller populations with short canopies subjected to continuous stocking management (Calvano et al., 2011; Matthew, Lemaire, Sackville-Hamilton, \& Hernández-Garay, 1995; Sbrissia \& Da Silva, 2008). This is essentially a consequence of competition for light (Sackville-Hamilton, Matthew, \& Lemaire, 1995) since reduced light availability at the base of the canopy is one of the main factors interfering with the tillering process of canopies grazed leniently. This observation could be confirmed by increases in light interception as canopy height increased (Table 4). In the first 2 years, the rates of herbage accumulation were similar among the different grazing intensities (Table 3). This fact may be attributed to a tiller size/density compensation mechanism that leads to a low population density of large tillers under lenient defoliation or a high population density of small tillers under intense defoliation (Hernández-Garay, Matthew, \& Hodgson, 1999; Matthew et al., 1995; Sbrissia \& Da Silva, 2008). Confirming these results, Da Silva et al. (2013) imposed four grazing intensities $(10,20,30$ and $40 \mathrm{~cm})$ on Marandu palisadegrass pastures for 1 year and did not observe differences in HAR.

However, after 2 years of grazing, canopies maintained at $15 \mathrm{~cm}$ presented a TPD equal to the TDP of canopies maintained at 30 or $45 \mathrm{~cm}$, indicating that Marandu canopies were not able to compensate for the reduced canopy height by increasing tiller numbers; consequently, a marked decline in the HAR was observed for pastures managed at a height of $15 \mathrm{~cm}$ (Table 3). This finding might be explained by decreasing levels of herbage mass and leaf area index (Table 4) and possibly declining carbohydrate reserves (Gomide, Gomide, Martinez y Huaman, \& Paciullo, 2002). Hernández-Garay et al. (1999) reported a similar situation for perennial ryegrass, where frequent defoliation resulted in lower TPD for their most severe defoliation treatment.

Among grazing strategies, grazing intensity plays the most prominent and consistent role in determining herbage mass (HernándezGaray et al., 2004; Sollenberger \& Vanzant, 2011; Stewart et al., 2007). Thus, the most lenient defoliation, associated with the $45 \mathrm{~cm}$ treatment, resulted in the highest herbage mass; however, it also had a lower leaf percentage and greater stem and dead material percentages than other treatments (Table 4). Conversely, the positive effect of grazing intensity on nutritive value (Table 4) may be associated with a reduction in the average maturity of the herbage mass. In contrast, the greater quantity of old leaves rejected by the grazing animals in canopies maintained at $45 \mathrm{~cm}$ most likely contributed to the lower nutritive value of this pasture (Table 4).

Despite greater nutritive value for pastures managed at $15 \mathrm{~cm}$, the average daily gain was lower for animals in those pastures than for animals in the other pastures. This could be attributed to inadequate herbage intake by the animals in the $15-\mathrm{cm}$ pastures (Table 4). It is possible that canopy height (Table 4) plays an important role in controlling bite mass and, consequently, instantaneous forage intake (Fonseca et al., 2013; Mezzalira et al., 2014). In this context, Da Silva et al. (2013) demonstrated that defoliation severity corresponded to 0.67 of the lamina length, regardless of defoliation frequency. Based 
TABLE 8 Averages and probability levels $(p)$ for herbage accumulation rate (HAR), herbage mass, percentages of leaf and dead material, crude protein, acid detergent lignin concentrations, in vitro organic matter digestibility (IVOMD), number of grazing days and average daily gain in Brachiaria brizantha cv. Marandu pastures subjected to continuous stocking, targeting either at 15, 30 or $45 \mathrm{~cm}$ canopy height, during dry periods of different experimental years

\begin{tabular}{|c|c|c|c|c|}
\hline & \multicolumn{3}{|c|}{ Experimental year } & \multirow[b]{2}{*}{$p$} \\
\hline & 2007 & 2008 & 2009 & \\
\hline $\operatorname{HAR}\left(\mathrm{kg} \mathrm{ha}^{-1}\right.$ day $\left.^{-1}\right)$ & $19.7 \mathrm{~b}(1.6)$ & $21.2 b(1.6)$ & $30.1 \mathrm{a}(1.6)$ & 0.0001 \\
\hline Herbage mass (kg/ha) & $3962 b(106)$ & $4145 b(106)$ & 4690a (106) & 0.0001 \\
\hline Leaf (\%) & $14.8 \mathrm{~b}(1.3)$ & $17.2 \mathrm{~b}(1.3)$ & $23.8 \mathrm{a}(1.2)$ & 0.0001 \\
\hline Dead material (\%) & $71.6 a(2.1)$ & $68.2 \mathrm{a}(2.0)$ & $60.3 b(1.9)$ & 0.0001 \\
\hline Crude protein (\%) & $9.1 \mathrm{a}(0.3)$ & $7.8 \mathrm{~b}(0.3)$ & $8.5 a b(0.3)$ & 0.0138 \\
\hline IVOMD (\%) & $56.8 \mathrm{a}(0.6)$ & $54.2 b(0.6)$ & $55.0 \mathrm{ab}(0.6)$ & 0.0060 \\
\hline $\begin{array}{l}\text { Number of grazing } \\
\text { days }\end{array}$ & $79 b(3.3)$ & $79 b(3.3)$ & $112 \mathrm{a}(3.1)$ & 0.0001 \\
\hline $\begin{array}{l}\text { Average daily gain (g/ } \\
\text { steer) }\end{array}$ & $370 a(25)$ & $262 b(23)$ & $382 \mathrm{a}(26)$ & 0.0029 \\
\hline
\end{tabular}

Note. Values in parentheses are standard errors of the mean (SEM).

Values followed by the same upper-case letter within the same column and the same lower-case letter within the same row were not significantly different according to the Tukey test at $p<0.05$. on that assumption, animals exploit only the top third of the canopy, a condition that would correspond to potential grazing strata of 5,10 and $15 \mathrm{~cm}$ for pastures maintained at 15,30 and $45 \mathrm{~cm}$ respectively. According to Hodgson, Clark, and Mitchell (1994), grazing horizons shorter than $10 \mathrm{~cm}$ corresponds to a serious restriction of bite formation, resulting in a significant reduction in bite mass, despite the high amount of leaf in the herbage consumed. Hodgson (1990) observed that under continuous stocking, forage intake and average daily gain increased at a decreased rate as canopy height increased. The point at which intake or performance approximates the maximum can be defined as the critical height because additional increases in canopy height will not improve animal performance and will result in a reduction in grazing efficiency. Based on this consideration, $30 \mathrm{~cm}$ was already in the range of the critical height for Marandu palisadegrass pasture (Table 4).

As a consequence of the way grazing was controlled to maintain canopy height targets, the stocking rate showed the same pattern of variation as described for forage accumulation rate (Table 3). In turn, the stocking rate affected animal performance directly and indirectly but was the major management strategy that affected gain per unit of land area. In this context, we could highlight the decrease of approximately $50 \%$ in the body weight gain per ha from the first to the third years for pastures managed at $15 \mathrm{~cm}$, while pastures managed at 30 or $45 \mathrm{~cm}$ decreased only $11 \%$ (Table 3 ) in the same period of time. Those decreases in productivity may not be primarily related to climate conditions since the first experimental year was characterized by the lowest rainfall distribution (Figure 1) during the rainy season compared with the same period in the following years (2008/2009). Together with high temperatures (Figure 1), those conditions resulted in a water deficit in the soil starting in March 2007 , which resulted in drought stress and a rainy season that was 2 months shorter in 2007 (Figure 2). The soil fertility levels of essential nutrients were close to the ones considered suitable for Marandu palisadegrass growth, especially $\mathrm{Ca}, \mathrm{Mg}$ and $\mathrm{K}$. Rao (2002) reported that $P$ is often the most limiting nutrient for pasture production in highly weathered acid soil in tropical America. This fact was observed during this trial regarding P levels. We were not able to keep soil $\mathrm{P}$ above critical levels during utilization and were incapable of achieving those criteria described in Martha Junior et al. (2007). This was the case since the beginning of this experiment. Soil $P$ levels (Mehlich-1) for pasture maintenance in this type of Oxisol (clayed and dystrophic) should be between 4 and $6 \mathrm{mg} / \mathrm{dm}^{3}$. P replacement, during utilization, was broadcasted as maintenance based on animal yield as reported in Martha Junior et al. (2007) at rates of $40 \mathrm{~kg} / \mathrm{ha}$ of $\mathrm{P}$ annually, but even so, soil $\mathrm{P}$ levels were below the ones required. In 2008, the P levels were relatively low and had a tendency to increase (Table 1 ) as a direct result of $P$ fertilization carried out over the subsequent years, but it was enough to maintain stable animal production, especially in more intensive pasture management at the $15 \mathrm{~cm}$ canopy height.

Despite the relatively constant canopy heights during the experimental period (Table 2), the forage mass was greater in 2008 (Table 5), likely due to some mistake in the stocking rate adjustment to keep pastures at target heights. The degradation in the canopy is characterized by an increased dead material percentage and a decreased leaf percentage over time (Table 5), mainly in the leniently grazed pastures, which seems typical for a continuously stocked pasture. These traits may have contributed to the lower crude protein and average daily gain observed in 2009 (Table 5).

\section{2 | Dry season}

In general, the effect of grazing intensity on the variables evaluated was very similar to the effect observed during the wet season (Tables 6 and 7). Short-length grazing periods in 2007 and 2008 (Table 8) were primarily related to drier-than-normal weather, extending the dry season until November (Figures 1 and 2). Conversely, the 2009 dry season was the most favourable for herbage production; thus, a canopy with a greater leaf proportion and a lower proportion of dead material was observed (Table 8). 
Independent of experimental years, the HAR was lower for the $15 \mathrm{~cm}$ treatment (Table 7). This response could be a consequence of the highest tiller mortality observed for canopies maintained at $15 \mathrm{~cm}(0.39,0.68$ and 0.62 were the means of the stability index observed for pastures at 15,30 and $45 \mathrm{~cm}$ respectively). Several studies have reported the highest rate of tiller death under severe grazing intensity (Carvalho et al., 2001; Hernández-Garay et al., 1999; Sbrissia et al., 2010).

Even by adjusting stocking rates (Tables 3 and 7), it was not possible to maintain the animals in some paddocks while still maintaining the target heights during the entire dry season; thus, the number of grazing days decreased with increased grazing intensity (Table 7). Additionally, the lower average daily gain of animals grazing in the $15-\mathrm{cm}$ pastures most likely reflected imposed grazing conditions, that is, short canopies, which limit bite mass; consequently, this negatively affected animal performance (Da Silva et al., 2013). Conversely, with a high herbage mass in the $45 \mathrm{~cm}$ treatment, the opportunity for diet selection may have overridden the relatively small forage nutritive value and maintained ADG similar to that in pastures maintained at $30 \mathrm{~cm}$ height (Table 7). Under those conditions, the body weight yield in the pastures managed at $15 \mathrm{~cm}$ was approximately $60 \%$ lower than the yield in pastures managed at 30 or $45 \mathrm{~cm}$ (Table 6).

There was a marked reduction in the HAR during the wet season, which corresponded to $18 \%, 29 \%$ and $31 \%$ of the annual accumulation in the pastures managed at 15, 30 and $45 \mathrm{~cm}$ respectively (Tables 3 and 7). This pronounced reduction in HAR during the dry season, regardless of the canopy height, resulted mainly from the water stress observed during this period (Figures 1 and 2). Additionally, the reduction in the leaf mass resulted in decreased crude protein (CP) and in vitro organic matter digestibility (IVOMD) in the herbage, as well as a decline in the leaf:stem ratio (Tables 4 and 7). These traits probably contributed to the lower animal performance observed during that season (Tables 4 and 7) and resulted in a marked decline in body WGA (Tables 3 and 8 ).

\section{3 | Persistence and productivity}

According to Islam and Hirata (2005), the seasonal variation in the tiller population is the basis for understanding the mechanisms affecting variation in yield and persistence of a grass pasture over time. In this context, the pattern of response in TPD (Figure 3) was typical of tropical regions, mainly as a consequence of rainfall seasonality (Figures 1 and 2). Similar TPD variations throughout the year for Marandu palisadegrass have been previously reported (Paula et al., 2012; Pereira et al., 2010; Sbrissia et al., 2010).

High tiller mortality for palisadegrass during periods of adverse climatic conditions has been documented by several authors (Calvano et al., 2011; Paula et al., 2012; Sbrissia et al., 2010). This may explain the pronounced decrease in TPD from summer to winter, regardless

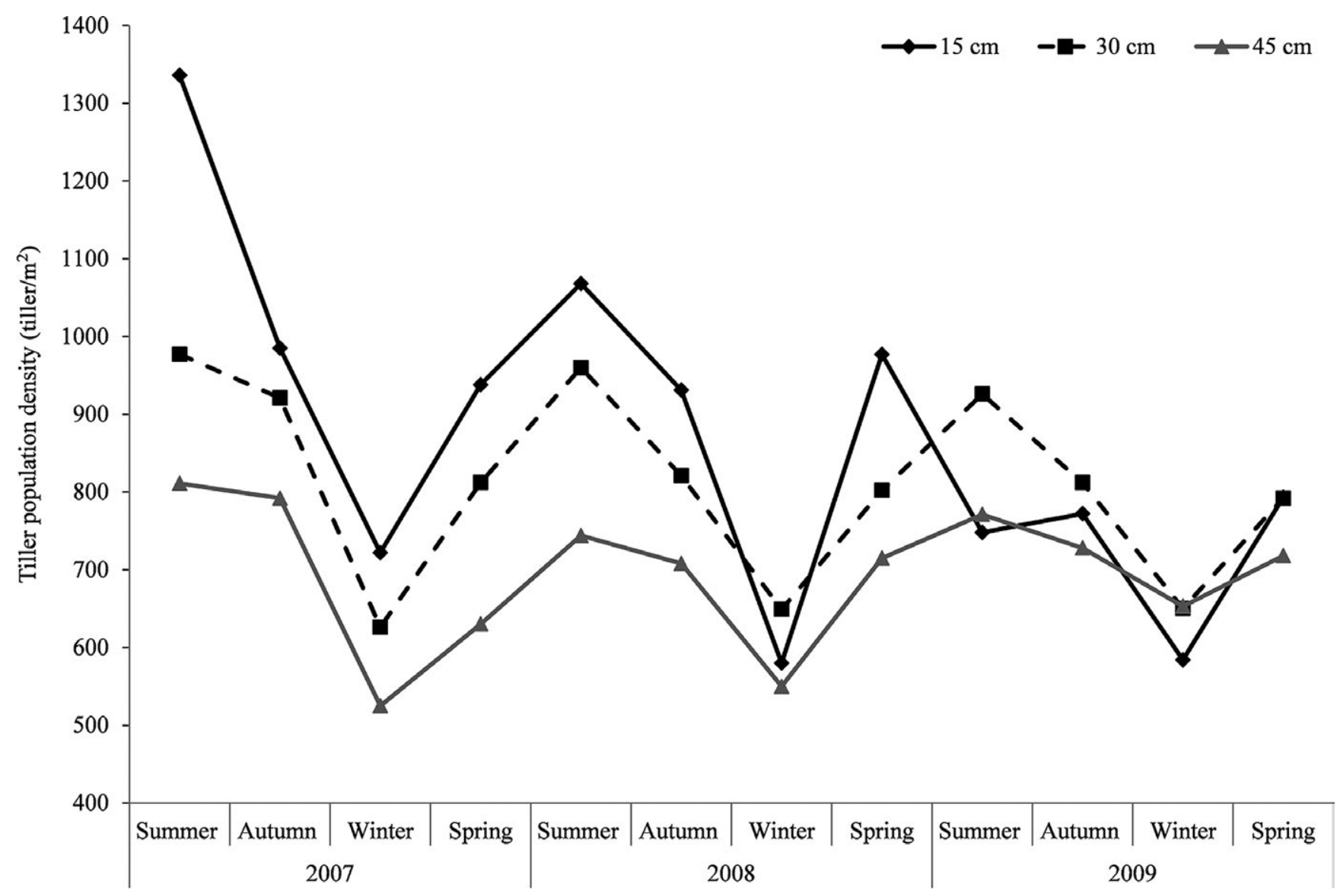

FIGURE 3 Effect of canopy height on tiller population density throughout the experimental period 


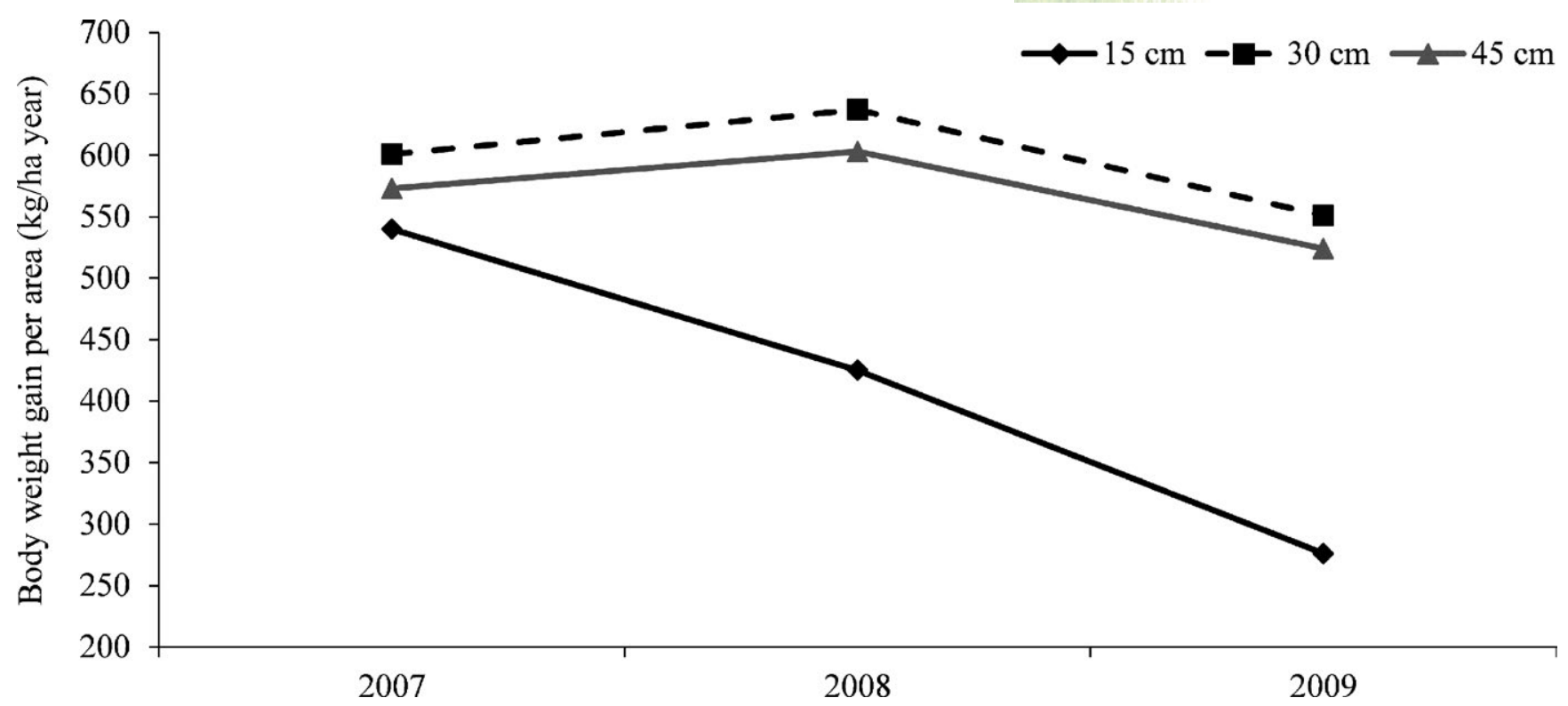

FIGURE 4 Effect of canopy height on annual body weight gain per area throughout the experimental period

of target height or experimental year (Figure 3). In contrast, spring and summer were characterized by high rates of tiller appearance as a consequence of more favourable climatic conditions (Figures 1 and 2) and the application of nitrogen fertilizer during summer.

Canopies managed at 30 or $45 \mathrm{~cm}$ efficiently replaced the dead tillers (Figure 3); consequently, there was less variation in the TPD during the rainy season throughout the experimental period, resulting in similar herbage yields across years (Table 2). Despite a decrease of approximately $10 \%$ in annual body WGA during the experimental period (Figure 4), this difference was not significant ( $p>0.05$ ); thus, the use of these target heights appears to be a sustainable management alternative.

In contrast, for canopies managed at $15 \mathrm{~cm}$ height, the number of tillers declined from year to year, suggesting that, although the climatic conditions found in spring and summer were favourable to the tillering process (Figures 2 and 3), they were not sufficiently favourable to promote increases in TPD or to compensate for the number of dead tillers observed during winter due to climatic constraints. Confirming these results, Sbrissia et al. (2010) conducted a tiller dynamics study with Marandu palisadegrass pasture continuously stocked to maintain canopy heights of $10,20,30$ and $40 \mathrm{~cm}$, and they suggested that maintaining canopies at $10 \mathrm{~cm}$ during summer may be prejudicial to persistence since the replacement of dead tillers does not occur during a time of year when tiller survival is low. Those authors warned that low TPD alone cannot be considered an adequate predictor of canopy productivity and longevity since palisadegrass shows tiller size density compensation (Sbrissia \& Da Silva, 2008). However, in this trial, the decline of TPD was associated with a marked reduction in herbage yield in the third year of grazing (Table 2) which, in turn, promoted reductions in pasture's carrying capacity and body WGA (Figure 4). Thus, these results indicated that maintaining canopies at $15 \mathrm{~cm}$ may be prejudicial to the persistence of Marandu palisadegrass pasture. In this context, Marshall (1987) suggested that the pasture degradation process may begin when the rates of tiller death are greater than rates of tiller appearance as a result of grazing mismanagement.

Although nitrogen fertilizer may arrest the process of pasture degradation, its use in Brazil is limited due to its high cost. Additionally, the lack of grazing management is common in Brazilian pastures, which results in low efficiency and consequently does not justify the use of nitrogen. For that reason, in this trial, the nitrogen fertilization used was relatively moderate (90 kg of $\mathrm{N} \mathrm{ha}^{-1}$ year $^{-1}$ ). The crucial point, however, is to keep soil $P$ levels at those indicated to sustain pasture and animal production over time (Martha Junior et al., 2007). Raising soil $P$ levels (Mehlich-1) from below $2 \mathrm{mg} / \mathrm{dm}^{3}$ up to $6-9 \mathrm{mg} / \mathrm{dm}^{3}$ could require significant doses of $\mathrm{P}$ fertilizer. Oxisols with these characteristics demand applications of $65-90 \mathrm{~kg}$ of $\mathrm{P} / \mathrm{ha}$ at one time to overcome soil $P$ fixation in these weathered soils. Once the target level is reached, to maintain pasture persistence, annual applications of $P$ should be performed based on the intensification of animal productivity to replace the $\mathrm{P}$ fixed and/or extracted by the complex soil-plant-animal system. This practice could be done gradually in many ways (Sousa, Nunes, Rein \& Santos Junior, 2016) and directly or indirectly (Macedo, 2009). Currently, one of these alternatives, which is being used more and more often by farmers, is the integrated crop-livestock system (CLIS), which has the ability to increase soil fertility levels in such a way that alleviates costs and increases cash flow to farmers, especially in the case of soil $\mathrm{P}$ (Macedo, 2009). It could also be noted that the $\mathrm{N}$ supply may not have been enough for plants to achieve the potential yield allowed by the actual climatic conditions, mainly for intensively grazed pasture (Lemaire, Jeuffroy, \& Gastal, 2008). However, this could be explained by the lower soil P observed. Limestone to overcome soil acidity and supply $\mathrm{Ca}$ and $\mathrm{Mg}$ and $\mathrm{K}$ fertilizer does not limit farmers of this soil due to their cost, but $P$ fertilizer does create a 
cost limitation. This trial is a demonstration of the importance of pasture management and of how amendment application and agronomic practices can help producers use sustainable alternatives.

\section{5 | CONCLUSIONS}

Management of Marandu palisadegrass pastures continuously stocked at a $15 \mathrm{~cm}$ canopy height on Oxisol under moderate fertilization (18 kg P/ha, $33 \mathrm{~kg} \mathrm{~K} / \mathrm{ha}$ and $90 \mathrm{~kg} \mathrm{~N} \mathrm{ha}^{-1}$ year $^{-1}$ ) maintained below the soil $\mathrm{P}$ levels required at pasture establishment ( $<80 \%$ of soil P-Mehlich-1 extractant) must be avoided. This scenario may decrease plant persistence and animal body WGA in the long term. However, the same Marandu palisadegrass pasture could be grazed at canopy heights of $30-45 \mathrm{~cm}$ for a period of at least 2-3 years with annual moderate fertilization without compromising herbage accumulation and body weight gains per animal and per area.

\section{ACKNOWLEDGMENTS}

The authors are grateful to FUNDECT (Mato Grosso do Sul State Foundation for Education, Science and Technology Development) and to CNPq (Brazilian National Council for Scientific and Technological Development) for partial funding of this research. They are also grateful to CNPq for the second and the fifth authors' research grant.

\section{ORCID}

Valéria P. B. Euclides (iD https://orcid.org/0000-0002-3149-482X

Denise B. Montagner (iD https://orcid.org/0000-0003-2688-8063

Manuel Cláudio M. Macedo (iD https://orcid.org/0000-0002-6054-9412

Alexandre R. Araújo iD https://orcid.org/0000-0003-1266-988X

Gelson S. Difante (iD https://orcid.org/0000-0001-6610-8952

Rodrigo A. Barbosa (iD https://orcid.org/0000-0002-0853-1805

\section{REFERENCES}

Allen, V. G., Batello, C., Berretta, E. J., Hodgson, J., Kothmann, M., Li, X., ... Sanderson, M. (2011). An international terminology for grazing lands and grazing animals. Grass and Forage Science, 66, 2-28. https:// doi.org/10.1111/j.1365-2494.2010.00780.x

Andrade, R. G., Bolfe, E. L., Victoria, D. C., \& Nogueira, S. F. (2016). Geotecnologia - Recuperação de pastagens no Cerrado. Agroanalysis, 36, 30-33. Retrieved from http://bibliotecadigital.fgv.br/ojs/index. php/agroanalysis/article/viewFile/63501/61592

Bahmani, I., Thom, E. R., Matthew, C., Hopper, R. J., \& Lemaire, G. (2003). Tiller dynamics of perennial ryegrass cultivars derived from different New Zealand ecotypes: Effects of cultivar, season, nitrogen fertilizer, and irrigation. Australian Journal of Agricultural Research, 54, 803-817. https://doi.org/10.1071/AR02135

Calvano, M. P. C. A., Euclides, V. P. B., Montagner, D. B., Lempp, B. Difante, G. S., Flores, R. S., \& Galbeiro, S. (2011). Tillering and forage accumulation in Marandu grass under different grazing intensities. Revista Ceres, 58, 781-789. https://doi.org/10.1590/ S0034-737X2011000600015

Carvalho, C. A. B., Da Silva, S. C., Sbrissia, A. F., Pinto, L. F. M., Carnevalli, R. A., Fagundes, J. L., \& Pedreira, C. G. S. (2001). Tiller demography and dry matter accumulation in coastcross grass under grazing. Pesquisa Agropecuária Brasileira, 36, 567-575. https://doi. org/10.1590/S0103-90162001000400003

Chapin III, F. S., Matson, P. A., \& Vitousek, P. M. (Eds.) (2012). Principles of terrestrial ecosystem ecology (pp. 63-90). New York, NY: Springer.

Da Silva, S. C., Gimenes, F. M. A., Sarmento, D. O. L., Sbrissia, A. F., Oliveira, D. E., Hernandez-Garay, A., \& Pires, A. V. (2013). Grazing behaviour, herbage intake and animal performance of beef cattle heifers on Marandu palisade grass subjected to intensities of continuous stocking management. The Journal of Agricultural Science, 151, 727-739. https://doi.org/10.1017/S0021859612000858

EMBRAPA (2017). App pasto certo. Retrieved from https://play.google. $\mathrm{com} /$ store/apps/details?xml:id=br.embrapa. pastocerto\&hl=pt_ BR\&rdxml:id=br.embrapa. pastocerto\&pli=1

EMBRAPA (2018). Sistema Brasileiro de Classificação de Solos (5th ed., rev. e ampl). Brasília, DF: Embrapa. E-book. Retrieved from http:// www.geografia.fflch.usp.br/graduacao/apoio/Apoio/Apoio_ Attila/1s2018/livros/Sistema_Brasileiro_Classificacao_de_Solo2018.pdf

Euclides, V. P. B., Montagner, D. B., Barbosa, R. A., Valle, C. B., \& Nantes, N. N. (2016). Animal performance and sward characteristics of two cultivars of Brachiaria brizantha (BRS Paiaguás and BRS Piatã). Revista Brasileira De Zootecnia, 45, 85-92. https://doi.org/10.1590/ S1806-92902016000300001

FAO (2009). The state of food and agriculture. Rome, Italy: FAO. Retrieved from http://bit.ly/dcsAFD.

Fonseca, L., Carvalho, P. C. F., Mezzalira, J. C., Bremm, C., Galli, J. R., \& Gregorini, P. (2013). Effect of sward surface height and level of herbage depletion on bite features of cattle grazing Sorghum bicolor swards. Journal of Animal Science, 91, 4357-4365. https://doi. org/10.2527/jas2012-5602

Gomide, C. A. M., Gomide, J. A., Martinez y Huaman, C. A., \& Paciullo, D. S. C. (2002). Fotossíntese, reservas orgânicas e rebrota do capimmombaça (Panicum maximum Jacq.) sob diferentesintensidades de desfolha do perfilho principal. Revista Brasileira De Zootecnia, 31, 2165-2175. https://doi.org/10.1590/S1516-35982002000900003

Hernández-Garay, A., Matthew, C., \& Hodgson, J. (1999). Tiller size density compensation in ryegrass miniature swards subject to differing defoliation heights and a proposed productivity index. Grass and Forage Science, 54, 347-356. https://doi. org/10.1046/j.1365-2494.1999.00187.x

Hernández-Garay, A., Sollenberger, L. E., McDonald, D. C., Ruegsegger, G. J., Kalmbacher, R. S., \& Mislevy, P. (2004). Nitrogen fertilization and stocking rate affect stargrass pasture and cattle performance. Crop Science, 44, 1348-1354. https://doi.org/10.2135/cropsci2004.1348

Hodgson, J. (1990). Grazing management-science into practice (p. 203). Essex, UK: Longman Scientific \& Technical.

Hodgson, J., Clark, D. A., \& Mitchell, R. J. (1994). Foraging behaviour in grazing animals and its impact on plant communities. In G. C. Fahey (Ed.), Forage quality, evaluation and utilization (pp. 796-827). Madison, WI: American Society of Agronomy, Crop Science Society of America, Soil Science of America.

Islam, M. A., \& Hirata, M. (2005). Leaf appearance, death and detachment, and tillering in centipede grass [Eremochloao phiuroides (Munro) Hack.] in comparison with bahiagrass (Paspalum notatum Flügge.): A study at a small sod scale. Grassland Science, 51, 121-127. https://doi. org/10.1111/j.1744-697X.2005.00017.x

Lemaire, G., Jeuffroy, M.-H., \& Gastal, F. (2008). Diagnosis tool for plant and crop $\mathrm{N}$ status in vegetative stage: Theory and practices for crop 
$\mathrm{N}$ management. European Journal of Agronomy, 28, 614-624. https:// doi.org/10.1016/j.eja.2008.01.005

Macedo, M. C. M. (2009). Integração lavoura-pecuária: O estado da arte e inovações tecnólicas. Revista Brasileira De Zootecnia, 38, 133-146. https://doi.org/10.1590/S1516-35982009001300015

Marshall, C. (1987).Physiological aspects of pasture growth.InR. W. Snaydon (Ed.), Managed grasslands: Analytical studies. Ecosystem of the world (pp. 29-46). Amsterdam, The Netherlands: Elsevier.

Martha Junior, G. B., Vilela, L., \& Sousa, D. G. (2007). Cerrados: Uso eficiente de corretivos e fertilizantes em pastagens (p. 224). Planaltina, Brazil: Embrapa Cerrados.

Matthew, C., Lemaire, G., Sackville-Hamilton, N. R., \& Hernández-Garay, A. (1995). A modified self-thinning equation to describe size/density relationships for defoliated swards. Annals of Botany, 76, 579-587. https://doi.org/10.1006/anbo.1995.1135

Mezzalira, J. C., Carvalho, P. C. F., Fonseca, L., Bremm, C., Cangiano, C., Gonda, H. L., \& Laca, E. A. (2014). Behavioural mechanisms of intake rate by heifers grazing swards of contrasting structures. Applied Animal Behaviour Science, 153, 1-9. https://doi.org/10.1016/j. applanim.2013.12.014

Paula, C. C. L., Euclides, V. P. B., Lempp, B., Barbosa, R. A., Montagner, D. B., \& Carloto, M. N. (2012). Acúmulo de forragem, características morfogênicas e estruturais do capim-marandu sob alturas de pastejo. Ciência Rural, 42, 2059-2065. https://doi.org/10.1590/ S0103-84782012005000084

Pereira, L. E. T., Paiva, A. J., Da Silva, S. C., Caminha, F. O., Guarda, V. A., \& Pereira, P. M. (2010). Sward structure of Marandu palisadegrass subjected to continuous stocking and nitrogen-induced rhythms of growth. Scientia Agricola, 67, 531-539. https://doi. org/10.1590/0103-9016-2014-0013

Rao, I. M. (2002). Role of physiology in improving crop adaptation to abiotic stresses in the tropics: The case of common been and tropical forages. In M.Passarakli (Ed.), Handbook of plant and crop physiology (pp. 583-613). New York, NY: Marcel Dekker.

Sackville-Hamilton, N. R., Matthew, C., \& Lemaire, G. (1995). In defence of the $-3 / 2$ boundary rule: $A$ re-evaluation of self thinning concepts and status. Annals of Botany, 76, 569-577. https://doi.org/10.1006/ anbo.1995.1134

Sbrissia, A. F., \& Da Silva, S. C. (2008). Compensação tamanho/densidade populacional de perfilhos em pastos de capim marandu. Revista Brasileira De Zootecnia, 37, 35-47. https://doi.org/10.1590/ S1516-35982008000200006

Sbrissia, A. F., Da Silva, S. C., Sarmento, D. O. L., Molan, L. K., Andrade, F. M. E., Gonçalves, A. C., \& Lupinacci, A. V. (2010).
Tillering dynamics in palisadegrass swards continuously stocked by cattle. Plant Ecology, 206, 349-359. https://doi.org/10.1007/ s11258-009-9647-7

Sollenberger, L. E., \& Cherney, D. J. R. (1995). Forages. In R. F. Barnes, D. A. Miller, \& C. J. Nelson (Ed.), Evaluating forage production and quality (Vol. 2, pp. 97-110). Ames, IA: lowa State University Press.

Sollenberger, L. E., \& Vanzant, E. S. (2011). Interrelationships among forage nutritive value and quantity and individual animal performance. Crop Science, 51, 420-432. https://doi.org/10.2135/ cropsci2010.07.0408

Sousa, D. M. G., Nunes, R. S., Rein, T. A., Santos Junior, J. D. G. (2016). Manejo do fósforo na região de Cerrado. In: Flores, R. A., Cunha, P. P. (Eds.), Prática de manejo do solo para adequada nutrição de plantas no Cerrado (1 edn), pp. 291-357. Goiânia-GO: UFG.

Stewart, R. I., Sollenberger, L. E., Dubeux, J. C. B., Vendramini, J. M. B., Interrante, S. M., \& Newman, Y. C. (2007). Herbage and animal responses to management intensity of continuously stocked Bahiagrass pastures. Agronomy Journal, 99, 107-112. https://doi.org/10.2134/ agronj2006.0167

Thornthwaite, C. W., \& Mather, R. J. (1955). The water balance (Vol. 8, p. 104). Centerdon, NJ: Laboratory of Climatology.

USDA (2014). Keys to soil taxonomy (12th ed., p. 360). Washington, DC: Department of Agriculture, Natural Resources Conservation Service, Soil Survey Staff.

Valadares Filho, S. C., Paulino, P. V. R., \& Sainz, R. D. (2005). Desafios metodológicos para determinação das exigências nutricionais de bovinos de corte no Brasil. In Proceedings Annual Meeting of Sociedade Brasileira de Zootecnia, 45, 261-287.

Williams, C. H., David, D. J., \& Ilsmaa, O. (1962). The determination of chromic oxide in feces samples by atomic absorption spectrophotometry. The Journal of Agricultural Science, 59, 381-385. https://doi. org/10.1017/S002185960001546X

How to cite this article: Euclides VPB, Montagner DB, Macedo MCM, de Araújo AR, Difante GS, Barbosa RA. Grazing intensity affects forage accumulation and persistence of Marandu palisadegrass in the Brazilian savannah. Grass Forage Sci. 2019;00:1-13. https://doi. org/10.1111/gfs.12422 